\title{
Strategies for Controlling and Monitoring Water Quality in the Central African Water Distribution Company (SODECA)
}

\author{
Alafei Nama Janice Sandrine (Corresponding author) \& Hong Jun \\ China University of Geosciences, School of Environmental Studies \\ 388 Lumo Road, Hongshan Administrative District, Wuhan 430074, Hubei, China \\ Tel.: 86-27-5983-9746 E-mail: namajanice@yahoo.fr \\ Yves Yalanga \\ Central African Water Distribution Company (SODECA) \\ Tel.: 236-7550-5086 E-mail: yves_yalanga@yahoo.fr
}

\begin{abstract}
The present study investigated the strategies for controlling and monitoring water quality in the Central African Water Distribution Company. Several important monitoring measurements were done to ascertain the water quality at different stages of the production line, such as physico-chemical, limnology and bacteriological. According to the results, sometimes the frequency of controls undergoes a modification in time. This justifies the reduction of the number of controls. The breaking-off the reagent causes also a reduction of the number of analyses. The frequency of physicochemical control is much more respected compared to the bacteriological and limnologic controls. Therefore, it is recommended to have laboratory equipment with high technical instrument, and highly trained work force; the regular supply of reagents used in analyses of quality control; the revision of method, mode of analyses of control, monitoring and distribution.
\end{abstract}

Keywords: Drinking water quality, Monitoring, Strategy, SODECA

\section{Introduction}

Water quality is the physical, chemical, and biological characteristics of water. For example, water that is to be used for drinking should not contain any chemicals or micro-organisms that could be hazardous to health. Reference is frequently made to a set of standards from which compliance can be assessed. The most common standards used to assess water quality relate to drinking water, safety of human contact and for the health of ecosystems. Safe and potable water is the basis for good human health. Water provides essential elements, but when polluted it may become the source of undesirable substances dangerous to human health (Karavoltsos et al., 2008). On a continuing basis around the world an estimated 1.8 million people die every year from diarrheal diseases (including cholera). The majority of these deaths are among children in developing countries and up to $39 \%$ of diarrheal disease could be prevented by household water treatment by chlorination (WHO, 2004a). By contrast, drinking water safety is largely

taken for granted by many citizens of affluent nations. The availability of drink water delivered to households without of consumers becoming ill may be one of the key defining characteristics of developed nations in relation to the majority of the world. Valuing that enormous benefit appropriately must be a core value guiding risk management in the drinking water business. (Hrudey et al., 2006). Therefore, appropriate systems are designed to facilitate sustainable monitoring of regular and emergency release attributes with human health factors, and economic impacts. The data from these monitoring facilities help decision makers identify problems, documentation, and demonstrate overall trends in water quality. Thus, it is crucial to review the current network design procedures and develop basic guidelines in the design, expansion, and relocation of surface water quality monitoring networks from time to time. In recent years, the adequacy of collected water quality data and the performance of existing monitoring networks have been extensively evaluated for two basic reasons. First, an efficient information system is required to satisfy the needs of water quality management plans and to aid in the decision making process (Harmancioglu et al., 1998). Secondly, this system has to be realized under the constraints of limited financial resources, sampling and analysis facilities, and manpower. To ensure cost-effectiveness, an evaluation strategy adopted for a water quality monitoring network should cover all relevant technical design features, including selection of sampling sites, sampling frequencies, variables to be monitored, sensors synergy, and sampling duration (Loftis and Ward, 1980). As a result, existing monitoring networks will have to be adapted to new requirements. In the majority 
of cases, the location and the density of monitoring points will need to be adapted to provide adequate spatial coverage (surveillance monitoring) and to capture the effect of individual (main) pressures (operational and investigative Monitoring). Furthermore, more substances should be monitored in a more systematic manner, particularly those listed as priority substances. From a technical perspective, the main challenges will comprise establishing new monitoring networks (selection of representative monitoring points), developing information systems for managing an increasing volume of data coming from different producers (Chery et al., 2005), developing new analytical methods and controlling measurement uncertainty (Coquery et al., 2005). From an economic perspective, the challenge will be to minimize monitoring cost. In some cases, organizational changes might also be necessary, with possible redistribution of tasks and responsibilities within or between organizations, be they private, public, national and/or regional. (Graveline et al., 2010). Harmancioglu et al., (1998) summarized the technologies and solutions for planning and designing various water quality monitoring networks. Information retrieval from the monitoring networks has turned out to be critical, recently leading the development of a variety of visualization techniques that might be useful for demonstrating important aspects of a water quality monitoring network (Boyer et al., 2000).

Central African Republic Government has endorsed the basic principles of the World Water Vision; by creating National Water and Sanitation body (CNEA) that is responsible for defining and monitoring national policy on water and sanitation, ensuring the coordination of various sector's institutions and implementing the program of the International Decade for Drinking Water and Sanitation (IDWSSD, 1981-1990). It also adopted in 1983 the first strategic national policy documentation on water and sanitation. Therefore, the Central Africa Water Distribution Company (SODECA) was established to provide good water quality to the people. Its water quality laboratory is to provide city staff and citizens with the high quality water and data needed to ensure the safety of the water supply, make informed decisions, and maintain regulatory compliance for potable water. However, financial problems and outdated facilities have negatively affected this primary function of the company.

This study reviews the organization and working procedures of SODECA; highlighting the control system of water quality at this company based on the design of a monitoring program that efficiently and effectively generates data that serve management decision needs such as:

- $\quad$ Establishing, reviewing, and revising water quality standards

- Determining water quality standards attainment

- Identifying causes and sources of water quality impairments

\subsection{Strategies for controlling and monitoring}

Scientists use water quality data, collected in extensive monitoring and research programs, to assess the condition of aquatic ecosystems, and the effectiveness of environmental policies and management practices. Monitoring strategies are designed to characterize water quality, identify impacts from a variety of sources, provide a systematic and integrated framework for gathering necessary information to support decision making process. And ensure that at all times, the water supplied to the country's population is consistent with current standards. SODECA performs quality checks on inlet water at factory and consumer taps to determine the physicochemical and bacteriological aspect of the water produced at any given point in time.

\subsubsection{Type of control analysis}

In order to effectively monitor the water quality, SODECA has established a testing program; physico-chemistry, limnology and bacteriology. This laboratory is required to perform such checks regularly to ensure better water quality supply.

\subsubsection{Physicochemical control}

Physicochemical control is performed at all stages of processing and distribution of water in order to judge the effectiveness of treatment adopted and to verify whether the water supplied has the characteristics required for drinking water. The parameters monitored are: $\mathrm{pH}$, turbidity, alkalinity, conductivity, temperature, total hardness, iron, manganese, color, nitrates, nitrites, sulfur and phosphate (Grelaud \& Oudar, 1996).

\subsubsection{Bacteriological control}

Drinking water may be a means of transmitting many serious infectious diseases. Therefore drinking water bacteriological quality is of great importance, and the monitoring of bacterial indicators such as total coliforms, and fecal coliforms must be especially in ensuring that the bacteriological quality of water produced and distributed within the international limit of less than $100 \mathrm{ml}$ total coliform and fecal in $100 \mathrm{ml}$ of sample. These analyses were carried out 
in 'SODECA' and 'Institute Pasteur'. These controls are based on study of colonies such as yeasts and moulds, coliform and total bacteria: and carried out twice a month if there's availability of reagents.

A further examination is conducted monthly at the 'Institute Pasteur', for research on germs witnessing a fecal contamination such as Escherichia coli, fecal streptococci, and Clostridium sulfite reducers, total aerobic bacteria at $30^{\circ} \mathrm{C}$, total aerobic bacteria at $37^{\circ} \mathrm{C}$, heat-resistant coliforms and coliforms. These analyses were performed at the source point in the treated water, on points of special water fountains, and then selected in each distribution area reservoir, especially toward the ends of the network (Grelaud \& Oudart, 1996).

\subsubsection{Limnological test}

Limnological analysis is conducted twice a month in rainy period on raw water, and weekly in case of proliferation in the SODECA laboratory, in order to identify the types of algae that can give the water unpleasant taste and odor and initiate anti-algal (Onpe, 1996).

\section{Materials and Methods}

\subsection{Methods of physicochemical Analysis}

\subsubsection{Volumetric method}

The principle consists of adding in a known and precise volume of standard solution (deci normal in general) to water under analysis. The end of reaction is highlighted by a color indicator or a sudden change in $\mathrm{pH}$. This method allows the determination of complete alcalimetric title (CAT), oxidizability of potassium permanganate $\left(\mathrm{KMnO}_{4}\right)$, Total Hydrometric title (THT) and total calcium hardness (THCA). (Afnor, 1990 and Jean Rodier, 1984)

\subsubsection{Nephelometric Method}

It is based on the comparison of light diffracted by the sample to a reference standard in the same conditions. This method allows the determination of water turbidity (Afnor, 1990 \& Rodier, 1984).

\subsubsection{Colorimetric method}

This is one of the most used methods in water analysis. Its principle consists of developing a specific reaction color of an element of concern in the samples, and comparing the intensity of the color obtained with a set of standard. The standard color may result from the use of colored screens. This method is applied for measuring $\mathrm{pH}$, residual chlorine, etc. (Afnor, 1990 \& Rodier, 1984).

\subsubsection{Potentiometric Method}

This method measures the potential difference between a working electrode and a reference electrode under the same conditions. It is used for determining conductivity, temperature, pH etc. (Afnor, 1990 \& Rodier, 1984).

\subsubsection{Photometric method}

It is the most accurate analytical method in water analysis. It requires the preliminary implementation of a specific colored reaction of the element sought. It relies on the fact that the dye solution passes through a beam of light, absorbs an amount equivalent to the concentration of elements in it. This method allows the determination of: $\mathrm{Fe}^{2+,}$ $\mathrm{SO}_{4}^{2-}, \mathrm{Cl}^{-}, \mathrm{S}^{2-}, \mathrm{Al}^{3+}, \mathrm{NO}^{3-}, \mathrm{PO}_{4}^{3-}$, etc. (Afnor, 1990 \& Rodier, 1984).

\subsection{Bacteriological analysis method}

2.2.1 Millipore sampler's method is used at Central African Water Distribution Company (SODECA) to detect the water contaminants in drinking water. This method identifies the different germs on a specific culture medium that could be their colors.

- Yellow Sampler is specific for yeasts and molds;

- Blue for total coli form colonies;

- $\quad$ Red for total bacteria colonies.

The sampler is immersed in water for few moments and incubated at specific temperatures to find out the specific gems in the water sample. (Grelaud \& Oudart, 1996).

\subsubsection{Method of analysis conducted at the 'Institute Pasteur'}

The microbiological monitoring of water supplied at 'Institute Pasteur' involves the collection, incubation, enumeration isolation, identification and interpretation of results by the following methods:

- Incorporation in agar;

- Membrane filtration;

- Incorporation in agar deep tube. 
The main steps in the analysis are: collection, the setting in culture, the enumeration in insulation, identification, and interpretation of results.

\subsection{Limnological analysis method}

Limnological analysis is to identify the algal species that disrupt the treatment process by clogging filters, odor, taste changes and the risk of proliferation in drinking water pipes in case of infiltration. Its principle is to spin a certain volume of the sample and observe under a microscope the nerve between the blade and the slide in order to identify the different species present in the water sample (Hach, 1986).

\section{Results and Discussions}

\subsection{Results}

\subsubsection{Frequencies of analyses of water control}

The frequency of analyses on water is shown in table 1 .

The parameters are grouped as types.

Type I: Temperature, $\mathrm{pH}$, turbidity, CAT, Conductivity.

Type II: Oxidizability KMnO4.

Type III: Rates of alumina sulphate treatment.

Type IV: Identifying algal (twice monthly).

Type V: $\mathrm{Fe}^{2+}, \mathrm{NO}_{2}^{-}, \mathrm{NO}_{3}^{-}, \mathrm{S}^{2-}, \mathrm{Mn}^{2+}, \mathrm{NH}_{4}^{+}, \mathrm{PO}_{4}^{3-}, \mathrm{SO}_{4}{ }^{3-}$, THT, THMg, THCA, $\mathrm{Ca}^{2+}, \mathrm{Mg}^{2+}$, True Color.

Table 2 shows the number of physicochemical parameters controls carried out during three successive months. The Central African Water Distribution Company conducted 133 inspections in November, 126 inspections in December and further 128 inspections in January. The November data lacks some water controls parameters, probably due to the lack of reagents.

Table 3 shows that no Limnological control was performed during the month of November, however only one Limnological control was done during the months of December and January.

Table 4 shows that during November to January, the determination of treatment rates of alumina sulphate was regular. The absence of determination of calcium hypochlorite and lime treatment rates was reported as done to the failure of proportioning pumps.

\subsubsection{Frequencies of analyses of water during treatment}

The numbers of determination of the physicochemical parameters of water during treatment are more or less good, owing to the fact that certain parameters are below the control standard (Table 5 and 6).

3.1.3 Frequencies of analysis of treated water (From the factory)

Table 7 shows values of various parameter groups:

Type I: $\mathrm{Cl}_{2}$, temperature, $\mathrm{pH}$, turbidity, CAT, Conductivity.

\section{Type II: Oxidizability $\mathrm{KMnO} 4$.}

Type III : $\mathrm{Cu}^{2+}, \mathrm{Al}^{3+}, \mathrm{NO}_{2}^{-}, \mathrm{S}^{2-}, \mathrm{Cl}^{-}, \mathrm{Fe}^{2+}, \mathrm{Mn}^{2+}, \mathrm{NH}_{4}{ }^{+}, \mathrm{NO}_{3}^{-}, \mathrm{PO}_{4}{ }^{3-}, \mathrm{SO}_{4}{ }^{2-}, \mathrm{THT}, \mathrm{THMg}, \mathrm{THCa}, \mathrm{HCO}_{3}^{-}, \mathrm{Ca}^{2+}, \mathrm{Mg}^{2+}$.

Table 8 shows, all the parameters are within the acceptable levels, except the residual chlorine and oxidability in $\mathrm{KMnO} 4$.

3.1.4 Frequencies of analyses of treated water (From the factory and on the distribution networks)

Table 9 shows the different parameters like Physico-chemistry: $\mathrm{Cl}_{2}, \mathrm{pH}$, temperature, turbidity, $\mathrm{CAT}, \mathrm{NO}_{3}^{-}, \mathrm{Al}^{3+}$, $\mathrm{Cu}^{2+}, \mathrm{SO}_{4}^{2-}, \mathrm{Fe}^{2+}$, Color.

Bacteriology: Yeasts and molds, coliforms and total bacteria are determined in SODECA laboratory, while fecal streptococci, Clostridium sulfite reducers, total coliforms, total aerobic bacteria at $30^{\circ} \mathrm{C}$, and total aerobic bacteria at $37^{\circ} \mathrm{C}$ are determined at 'Institute Pasteur'.

In addition table 10 and 11 shows the results of inspections carried out at the 'Institute Pasteur' in Bangui.

\subsection{Discussions}

3.2.1 Statistics of controls carried out, and their interpretations

Statistical analyses were done on the data obtained for November to January during 2003 to 2007 period and are illustrated in figures (1-6). 


\subsubsection{Statistics of control of raw water}

\subsubsection{Total number and frequency control physicochemical variables and their percentages}

In the years 2003-2004 and 2005-2006, the frequency of controls carried out was in conformity with the standard established initially by the water distribution firm in Central African .On the other hand, the years 2004-2005 and 2006-2007 present data parameters was lower than the known standard of controls. This fall could be due to a temporary halt of production during the year 2004-2005 and also the non availability of stock reagents of analyses at the water supply company in Central Africa. With the approach of the rupture, sometimes the frequency of controls undergoes a modification in time. This justifies the reduction of the number of controls. However, it should be recognized that the frequency of analyses is a very significant aspect in monitoring raw water quality which constantly varies in its characteristics. The regular knowledge of the physicochemical quality of raw water allows water handler to re-examine the treatment process with the aim of improve quality of water distributed for human consumption (Figure 1).

\subsubsection{Totals number of limnologic frequency and a number of control and their percentages}

As illustrated by the peaks, no limnologic control was carried out during the year 2003-2004. This is because the SODECA had technical problems within that period. However, in the years 2004-2005, 2005-2006, 2006-2007, these analyses were carried out in accordance with the established frequency. A good identification is not possible unless the base collected after centrifugation is appreciable. Nevertheless, it is found that, the water becomes less turbid in dry periods, thus making the base a little tricky to obtain as show in figure 2.

\subsubsection{Totals of frequency and a number of determination of the rate of Treatments and their percentages}

The number of determination of treatment rates is constant during each year, while remaining very far below the established standard. From table 4, it is obvious that tests of chlorination and neutralization are non-existent. This result could be the disturbance during coagulation, due to inadequate $\mathrm{pH}$ of flocculation. Therefore, improper clarification a related to disinfection are caused by under dosage or over dosage (Figure 3).

\subsubsection{Statistics of control of water in treatment progress}

\subsubsection{Total frequency and number of controls during water treatment and their percentages}

In the first three years controls were more or less constant, although remaining below the standard. In the year 2006-2007, a considerable drops in the number of controls were observed, which could be related to a modification of the frequency of analyses for saving in reagents. The failure of this control may cause a disruption in processing as show in Figure 4.

\subsubsection{Statistics of treated water (from the factory)}

\subsubsection{Total frequency and number of physicochemical controls of the processed water and their percentages}

The physicochemical controls carried out on the water processed in the factory during 2003-2004 and 2004-2005 periods are in conformity with the established frequency. The deficits recorded in controls during the two last years are due to the breaking-off of the reagents, mainly the reagent Diethylparanylendiamine (DPD N1) on which it possible to control the effectiveness of disinfection (Figure 5).

\subsubsection{Statistics of treated water (from the factory and on the distribution networks)}

\subsubsection{Total frequency and number of physicochemical controls and their percentages}

The physicochemical controls carried out on the distribution network during the first three years are in conformity with the standards adopted by the water company in Central Africa. It would be judicious to double the frequency of these monitoring for more rigorous oversight of the state of the network because the dilapidated distribution network may lead to the alteration of the water quality flowing through it. The breaking-off of the reagents caused a reduction of the number of analyses on the physicochemical parameters such as: $\mathrm{Fe}^{2+}, \mathrm{Cl}_{2}, \mathrm{NO}_{2}^{-}, \mathrm{Al}^{3+}, \mathrm{SO}_{4}{ }^{2-}$, and $\mathrm{Cl}^{-}$ during the year 2006-2007 (Figure 6).

\subsubsection{Total numbers of frequency and bacteriological controls and their percentages}

The frequency of controls decreases year after year due to the following reasons: the irregularity in the payment of the invoices by the 'Institute PASTEUR' consequently denies it services to the 'SODECA' at times; the breaking-off of the Millipore samplers for bacteriological controls by the SODECA laboratory; the bacteriology is significant in the confirmation of the portability of water. So, it must be carried out as regularly as possible (Figure 7). 


\section{Conclusions and Suggestions}

Water is an essential element of life, not only for human organisms but for all living beings. The consumption of unsafe water which can cause a variety of health problems to man's, if it contains impurities. Therefore, a regular control and monitoring of water quality is essential. The frequency of controls on water quality must be established so that the excess amount of a given element can be detected very quickly. Monitoring the quality of water produced and distributed to the public is of great importance to the health of consumers. However, controls must be strengthened from the raw water intake to the consumer's tap. Based on the results obtained in this study, the following conclusions can be drawn:

- Sometimes the frequency of controls undergoes a modification in time. This justifies the reduction of the number of controls.

- The breaking-off of the reagent causes also a reduction of the number of analyses.

- The frequency of physicochemical control is much more respected compared to the bacteriological and limnologic controls.

And yet, the respect of the frequency of the analyses is a very significant aspect of monitoring. However, the regularity and the insurance in the realization of the physicochemical and bacteriological analyses constitute a guarantee in the control of quality of water produced.

Therefore, the 'SODECA' will have to pay much more attention on the following points in order to perform efficiently and effectively.

- The equipment of its laboratory with high technical instrument and highly trained work force;

- The regular supply of reagents of analyses for quality control;

- More qualified personnel should be involved in management, in order to gain the confidence of consumers on quality control issues;

- The revision of method, mode of analyses of control, monitoring and distribution;

- The sensitizing of the population on the importance of quality of drinking water.

\section{Acknowledgement}

This work was supported by the laboratory of the Central Africa Water Distribution Company (SODECA) and laboratory of Hydro Sciences LAVOISIER of university of BANGUI. The authors also extend thanks to colleagues in master's water quality class in university of BANGUI for their courage and collaboration in the study.

\section{References}

Association Française de Normalisation (AFNOR). (1990). $4^{\text {éme } e ́ d i t i o n, ~ T o m e ~ I ~ e t ~ I I . ~ E a u x ~ m e ́ t h o d e s ~ d ' e s s a i s . ~ P: ~}$ 414 et 734 .

Boyer, J.N., Sterling, P. \& Jones R.D. (2000). Maximizing Information from a Water Quality Monitoring Network through Visualization Techniques. Estuarine, Coastal, and Shelf Science, 50, 39-48.

Cosgrove,W. \& Rijsberman, F.R. (2000). World Water Vision: Making Water everybody's Business London. World Water Council, Earthscan Publications Ltd.

Chery, L. \& Thouin, C. (2005). 6th Int. EWRA Conf., European Water Resources Association. [Online] Available: http://www.ewra.net/.

Coquery, M., Morin, A., Be'cue, A. \& Lepot, B. (2005). Trends Anal. Chem., 24, 117.



Gadgil, A. (1998). Drinking water in developing countries. Annual Review of Energy and the Environment, 23, 253-286.

Grelaud, M. \& Oudart, I. (1996). Traitement des eaux potables nºt 2. Institut de Formation Professionnelle. P : 96 et 120 .

Graveline, N., Maton, L., Lu“ckge, H., Rouillard, J., Strosser, P., Palkaniete, K., Rinaudo, J.D., Taverne, D. \& Interwies, E. (2010). An operational perspective on potential uses and constraints of emerging tools for monitoring water quality. Trends in Analytical Chemistry, Vol. 29, No. 5

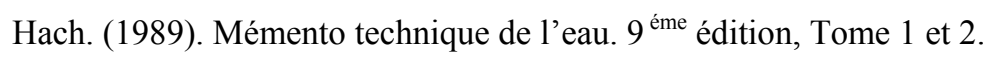


Harmancioglu, N.B. \& Alpaslan, N. (1992). Water Quality Monitoring Network Design: A Problem of Multi-Objective Decision Marking. Water Resources Bulletin, 28(1), 179-192.

Harmancioglu, N.B., Fistikoglu, O., Ozkul, S.D., Singh, V.P. \& Alpaslan, M.N. (1998). Water Quality Monitoring Network Design. Kluwer Academic Publishers, Dorbrecht, the Netherlands.

Hrudey, S.E., Hrudey, E. J., Pollard, S.J.T. (2006). Risk management for assuring safe drinking water. Environment International, 32, 948-957

Karavoltsosa, S., Sakellaria, A., Mihopoulosb, N., Dassenakisa, M., Scoullosa, M.J. (2008). Evaluation of the quality of drinking water in regions of Greece. Desalination, 224, 317-329

Loftis, J.C. \& Ward, R.C. (1980). Cost Effective Selection of Sampling Frequencies for Regulatory Water Quality Monitoring. Environment International, 3, 297-302.

Office National de l'Eau Potable (ONEP). (1996). Les algues dans les retenues de barrage utilisées pour la production d'eau potable au Maroc. Royaume du Maroc production d'eau. P : 104.

Rodier, J. (1984). Analyse de l'eau. $7^{\mathrm{eme}}$ édition. DUNOD Paris, 1365p.

WHO (World Health Organization). (2004a). Water, Sanitation and Hygiene Links to Health, Facts and Figures. World Health Organization

Table 1. Frequency of parameters used to control raw water

\begin{tabular}{ll}
\hline Periods & Monitored Parameters \\
\hline Daily & Type I and Type III \\
Weekly & Type II \\
Monthly & Type IV \\
Quarterly & Type V \\
\hline
\end{tabular}

Table 2. Number of determinations of physicochemical parameters during three months

\begin{tabular}{llll}
\hline & $\begin{array}{l}\text { November } \\
\text { 06 }\end{array}$ & $\begin{array}{l}\text { December } \\
\mathbf{0 6}\end{array}$ & January 07 \\
\hline Temperatures & 30 & 31 & 31 \\
$\mathrm{pH}$ & 30 & 31 & 31 \\
Turbidity & 30 & 31 & 31 \\
Conductivity & 30 & 31 & 31 \\
Oxidizability & 2 & 2 & 4 \\
$\mathrm{Fe}^{2+}$ & 0 & & \\
$\mathrm{NO}_{2}{ }^{-}$ & 0 & & \\
$\mathrm{NO}_{3}{ }^{-}$ & 0 & & \\
$\mathrm{~S}^{2-}$ & 0 & & \\
$\mathrm{Mn}^{2+}$ & 1 & & \\
$\mathrm{NH}_{4}{ }^{+}$ & 1 & & \\
$\mathrm{PO}_{4}{ }^{3-}$ & 1 & & \\
$\mathrm{SO}_{4}{ }^{2-}$ & 1 & & \\
$\mathrm{THT}_{\mathrm{THM}_{\mathrm{g}}}$ & 1 & & \\
$\mathrm{THC}_{\mathrm{a}}$ & 1 & & \\
$\mathrm{C}_{\mathrm{a}}{ }^{2+}$ & 1 & & \\
$\mathrm{M}_{\mathrm{g}}{ }^{2+}$ & 1 & & \\
$\mathrm{HCO}_{3}{ }^{-}$ & 1 & & \\
$\mathrm{Color}^{\mathrm{Total}}$ & 1 & & \\
\hline
\end{tabular}


Table 3. Determination of number of limnological control over three months

\begin{tabular}{llll}
\hline & November 06 & December 06 & January 07 \\
\hline Control Number & $\mathbf{0}$ & 1 & 1 \\
Total & $\mathbf{0}$ & 1 & 1 \\
\hline
\end{tabular}

Table 4. Determination of the rate of treatments carried out of the principal chemicals

\begin{tabular}{llll}
\hline Chemicals & November 06 & December 06 & January 07 \\
\hline Alumina Sulphate & 30 & 31 & 31 \\
$\begin{array}{l}\text { Calcium } \\
\text { hypochlorite }\end{array}$ & 0 & 0 & 0 \\
Lime & 0 & 0 & 0 \\
Total & 30 & 31 & 31 \\
\hline
\end{tabular}

Table 5. Frequency of physicochemical parameters used

\begin{tabular}{llll}
\hline $\begin{array}{l}\text { Daily } \\
\text { parameters }\end{array}$ & $\mathbf{p H}$ & Turbidity & $\mathbf{C l}_{\mathbf{2}}$ (case of pre chlorination) \\
Frequencies & 1 time $/ \mathrm{h}$ & 1 time / day & 1 time $/ \mathrm{h}$ \\
\hline
\end{tabular}

Table 6. Number of inspections conducted by the 'SODECA' company

\begin{tabular}{llll}
\hline & November 06 & December 06 & January 07 \\
\hline pH & 48 & 44 & 45 \\
Turbidity & 30 & 31 & 31 \\
Cl $_{2}$ & - & - & - \\
Total & 78 & 75 & 76 \\
\hline
\end{tabular}

Table 7. Frequency of physicochemical parameters

\begin{tabular}{ll}
\hline Periods & Monitored Parameters \\
\hline Daily & Type I \\
Weekly & Type II \\
Quarterly & Type III \\
\hline
\end{tabular}

Table 8 . The number of controls of the physicochemical parameters

\begin{tabular}{llll}
\hline & November 06 & December 06 & January 07 \\
\hline $\mathrm{Cl}_{2}$ & 76 & 98 & 103 \\
Temperature & 30 & 31 & 31 \\
Turbidity & 30 & 31 & 31 \\
pH & 30 & 31 & 31 \\
Conductivity & 30 & 31 & 31 \\
CAT & 30 & 31 & 31 \\
$\mathrm{Oxidizability}^{2+}$ & 2 & 2 & 4 \\
$\mathrm{Cu}^{2+}$ & - & - & - \\
$\mathrm{Al}^{3+}$ & 1 & & \\
$\mathrm{NO}_{2}{ }^{-}$ & 1 & & \\
$\mathrm{NO}_{3}^{-}$ & 1 & & \\
$\mathrm{Fe}^{2+}$ & 1 & & \\
$\mathrm{Cl}^{-}$ & 1 & & \\
$\mathrm{NH}_{4}{ }^{+}$ & 1 & & \\
$\mathrm{PO}_{4}{ }^{2-}$ & 1 & & \\
$\mathrm{SO}_{4}{ }^{2-}$ & 1 & & \\
$\mathrm{Mn}^{2+}$ & 1 & & \\
$\mathrm{THT}^{\mathrm{THMg}}$ & 1 & & \\
$\mathrm{THCa}_{\mathrm{HCO}_{3}}^{-}$ & 1 & & \\
$\mathrm{Ca}^{2+}$ & 1 & & \\
$\mathrm{Mg}^{2+}$ & 1 & & \\
$\mathrm{Total}$ & 1 & & \\
\hline & 243 & & \\
\hline
\end{tabular}


Table 9. Frequency of parameters used

\begin{tabular}{ll}
\hline Monitored Parameters & Monthly \\
\hline Physico-chemistry & 1 time \\
Bacteriology (SODECA & 2 time \\
company) & \\
Bacteriology (institute Pasteur) & 1 time \\
\hline
\end{tabular}

Table 10. The number of physicochemical controls carried out

\begin{tabular}{lll}
\hline & $\begin{array}{l}\text { December } \\
\text { 06 }\end{array}$ & January \\
& $\mathbf{0 7}$ \\
\hline Temperature & 1 & 1 \\
Turbidity & 1 & 1 \\
$\mathrm{pH}$ & 1 & 1 \\
$\mathrm{CAT}$ & 1 & 1 \\
$\mathrm{Iron}$ & 0 & 1 \\
$\mathrm{Cl}_{2}$ & 1 & 1 \\
$\mathrm{NO}_{2}{ }^{-}$ & 0 & 1 \\
$\mathrm{Al}^{3+}$ & 0 & 1 \\
$\mathrm{Cu}^{2+}$ & - & - \\
$\mathrm{SO}_{4}^{2-}$ & 1 & 1 \\
$\mathrm{Cl}^{-}$ & 1 & 1 \\
$\mathrm{Color}^{-2}$ & 1 & 1 \\
Total & $\mathbf{8}$ & $\mathbf{1 1}$ \\
\hline
\end{tabular}

Table 11. The number of bacteriological controls carried out at the institute Pasteur

\begin{tabular}{ll}
\hline & $\begin{array}{l}\text { Bacteriology } \\
\text { (Institut pasteur) }\end{array}$ \\
\hline November 06 & 0 \\
December 06 & 1 \\
January 07 & 1 \\
Total & $\mathbf{2}$ \\
\hline
\end{tabular}

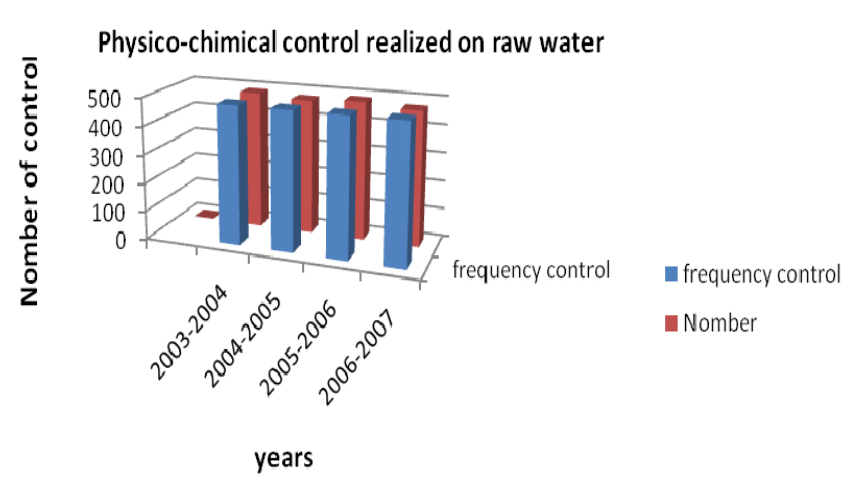

Figure 1. Evolution of physicochemical controls 




Figure 2. Evolution of the Limnologic control

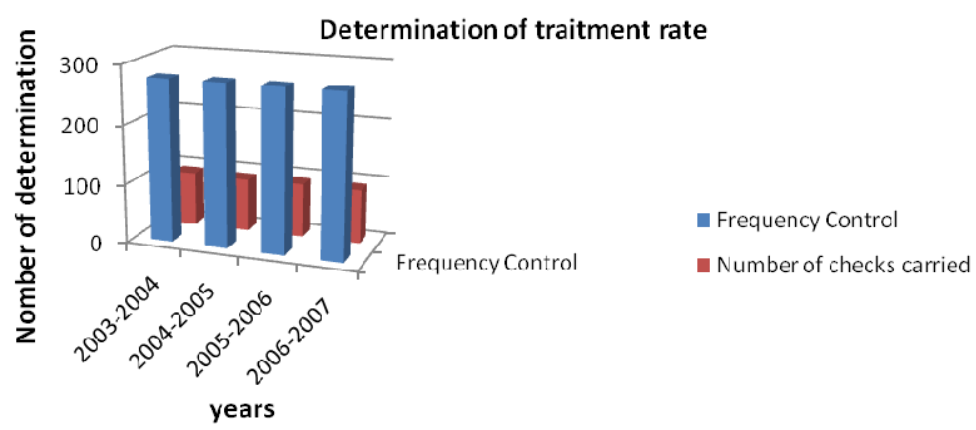

Figure 3. Evolution of the treatment rates

Control of the water during the treatment



Years

Figure 4. Evolution of control of the water during the treatment

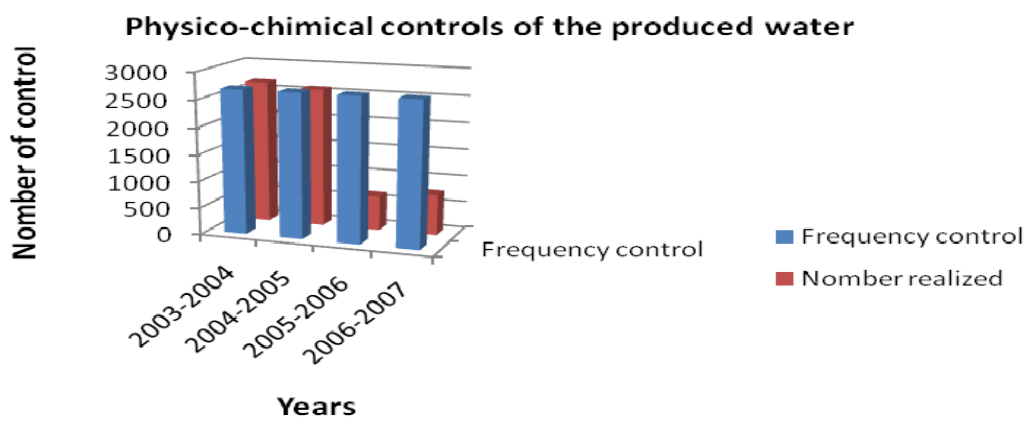

Figure 5. Evolution of physicochemical controls of the produced water 


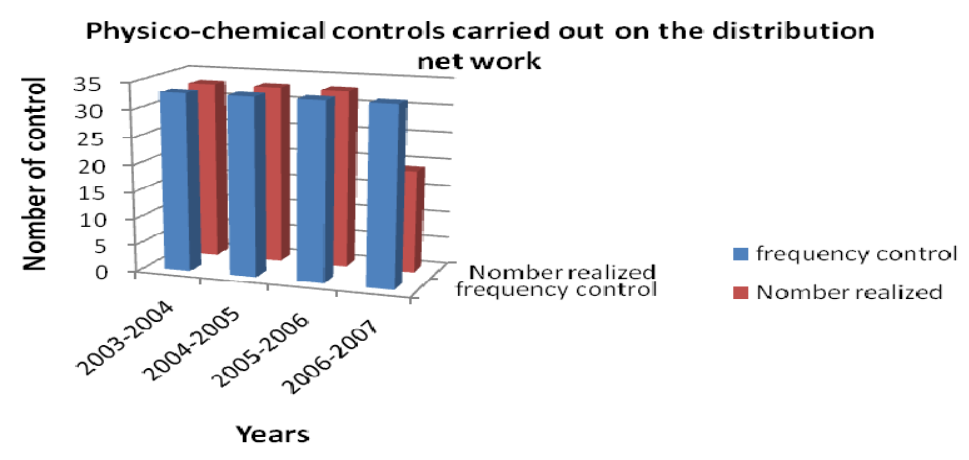

Figure 6. Evolution of physicochemical controls of the treated water

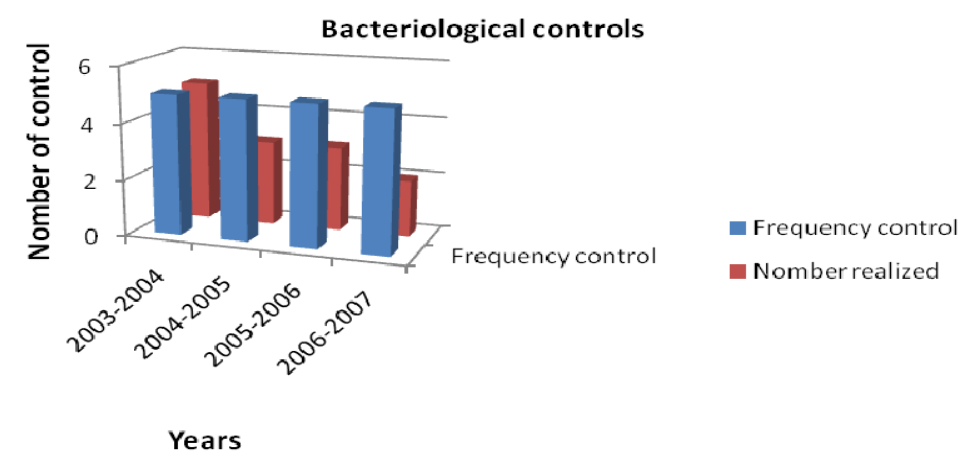

Figure 7. Evolution of bacteriological controls 